\title{
Evolution of the Socio-Economic Profile of the Entrepreneur in Galicia (Spain)
}

\author{
María de la Cruz del Río Rama ${ }^{1}$, José Álvarez García ${ }^{2} \&$ Carlos Rueda-Armengot ${ }^{3}$ \\ ${ }^{1}$ Faculty of Business Sciences and Tourism, University of Vigo, Vigo, Spain \\ ${ }^{2}$ Faculty of Business Studies and Tourism, University of Extremadura, Cáceres, Spain \\ ${ }^{3}$ Universitat Politècnica de València, Department of Business Adminstration, Valencia, Spain \\ Correspondence: María de la Cruz del Río Rama, Dpto. Organización de Empresas y Marketing, Universidad de \\ Vigo, As Lagoas SN, 32004 Ourense, Spain. Tel: 34-649-66-78-78. E-mail: delrio@uvigo.es
}

Received: February 19, 2014

Accepted: March 4, 2014

Online Published: March 12, 2014

doi:10.5430/bmr.v3n1p61

URL: http://dx.doi.org/10.5430/bmr.v3n1p61

\begin{abstract}
In this paper we analyze the evolution of both the level of entrepreneurship and the socio-economic profile of the entrepreneur in the Autonomous Community of Galicia (Spain) in the period 2007-2012, with the aim of observing the effects of the economic recession on the creation of new enterprises. The methodology used consists of analyzing the data provided by GEM Galicia reports developed within the framework of Global Entrepreneurship Monitor (GEM Project) by the observatory of entrepreneurial activity of Galicia, which ensures information on the behavior and profile of the entrepreneur. The results show that the economic recession in which Galicia is immersed caused a significant decline in entrepreneurial activity, entrepreneurship out of necessity increased and since the crisis began the entrepreneurial profile changed two of the socio-demographic variables considered: income level and specific training to undertake which both decreased.
\end{abstract}

Keywords: Entrepreneur, Profile, Global Entrepreneurship Monitor, Galicia (Spain)

\section{Introduction}

Boosting entrepreneurship has been a constant in the employment policy of the European Union (EU), as it regards the attitude towards entrepreneurship a driver for innovation, competitiveness and growth (Wennerkers and Thurik, 1999). According to Galindo and Mendez (2011:41), "Competitiveness in a broad sense is based on a series of pillars on which entrepreneurs play an important role. This together with the positive relationship they have with economic growth make it necessary to design appropriate measures to stimulate such activity".

In this sense, entrepreneurs are considered to be an important part of the job creation process and a growth-stimulating factor, as they create new enterprises, leading to greater wealth and well-being in a country (Galindo, 2009). This positive effect of entrepreneurship on economic growth is corroborated by numerous studies, including Audretsch, Bonte and Keilbach, 2008, Audretsch and Keilbach, 2004a, b, 2008 and Galindo et al, 2010.

The economy of the Autonomous Community of Galicia (Spain) is immersed in an economic context characterized by a severe economic recession that started in 2008 (it began to have a general visible effect in the second half of 2008), being one of the main problems faced by the Galician society with a high unemployment rate in December 2013 of $22 \%$ (22.3\% male and $21.6 \%$ female). The study conducted by Audretsch and Thurik (2004) shows that the crisis produces a double effect: on the one hand, the lack of expectations reduces the number of enterprises and on the other hand, the unemployment situation makes many people undertake due to the difficulty of finding a job. For all these reasons, self-employment (entrepreneurship) has become for the society of Galicia an opportunity to create jobs and thus reduce the unemployment rate, as well as a way to stimulate economic growth.

In this situation, it seems important to analyze the effects of the recession on the creation of new enterprises and on those enterprises already performing in the market, as some studies argue that there is a positive relationship between the unemployment rate and entrepreneurship, taking into account that the latter will be driven by the emergence of a wide range of unemployed with skills to become entrepreneurs (Audretsch and Thurik, 2001). We should also keep in mind that "the entrepreneurial activity can have positive effects on the different economic objectives which have been affected more severely in a negative way by the crisis"(Martin and Picazo, 2009:59), such as economic growth, employment and inflation.

Therefore, the aim of this paper is to show the evolution of the socio-economic profile of the entrepreneur in the Autonomous Community of Galicia (Spain) in the period 2007-2012, ie since the crisis impact to date, which will 
allow us to respond to a number of issues: Has the economic downturn affected the level of entrepreneurship?, Has there been a change in the socio-economic profile of the Galician entrepreneur in this economic recession context?, Have the obstacles that entrepreneurs are faced with when launching their projects with the advance of the crisis changed? And finally, have the determinant factors of the impulse of entrepreneurial activity in Galicia been altered?

\section{Methodology}

To carry out this analysis, the results derived from the Global Entrepreneurship Monitor (GEM) Observatory in Galicia from 2007 to 2012, have been used as a source of information. Data are collected annually by the GEM from two information sources: Adult Population Survey or APS and National Experts Survey or NES. To give an idea of the reliability of the study in the case of Galicia in 2012, the GEM Galicia conducted the survey of $1,772,288$ individuals residing in Galicia (total population) aged between 18 and 64 obtaining response from 2,000 individuals which represented a sampling error of $\pm 2.19 \%$ for the whole sample (Executive Report GEM Galicia, 212:16).

The Global Entrepreneurship Monitor (GEM) is a project which emerged in 1997 as a joint-investigation between Babson College (USA) and London Business School (UK), with the purpose of studying and comparing the entrepreneurial activity worldwide. So, the GEM arises as an international observatory with the objective of studying in depth the factors that impact on the enterprise creation phenomenon. Within the framework of the project, a detailed model of the business process and economic growth is built, which integrates the main variables provided by scientific research to the present day, including a wide range of factors associated with national variations which take place in the entrepreneurial activity and their key contextual characteristics (Reynolds et al., 2005).

Currently there are over 50 associated countries, among which Spain has been since 2000, besides being the only participating country that has developed a network of regional teams submitting annual reports and with the same degree of development as the national teams.

There are innumerable definitions of "entrepreneurship", being the one given by Wennekers and Thurik (1999) the most widely accepted, that define it "as the manifest capacity and desire of individuals, either by themselves or through teams, inside or outside existing organizations, to create new economic opportunities, ie new products, new forms of organization, new production methods, etc., and to introduce their ideas in the markets, facing uncertainty and other obstacles, adopting decisions on localization and on the manner and use of resources and institutions"(Galindo and Mendez, 2010:64). Therefore, "performing an entrepreneurial process does not necessarily require the emergence of a new company, even if some type of innovation takes place"(Kintana et al., 2007:121).

Given that to perform the analysis, the results of the Global Entrepreneurship Monitor (GEM) Observatory were used as a the main information source, we are going to take into account the definition of entrepreneur given by the GEM, which is considered as that adult (18 to 64 years old), who is immersed in a process of setting up a business or enterprise (nascent initiatives, less than 3 months of activity and new initiatives, between 3 months and $31 / 2$ years) or consolidating business (exceeding $3 \frac{1}{2}$ years of activity) and owns part or all of the business and/or is the owner or manager of a business or young company, including self-employment (GEM Galicia, 2012:13-15).

\section{Characteristics of the Galician Entrepreneur During the Recession. Period 2007-2012}

The unit of measurement of entrepreneurship used by the GEM is called TEA index (Total Early-stage Entrepreneurial Activity Index), that corresponds with the level of entrepreneurial activity in an economy and is equivalent to the incidence of nascent initiatives (from 0-3 months of activity) and new initiatives ( 3 to 42 months) measured in percentage of the population aged 18 to 64. In the case of Galicia, the period 2007-2012 is shown in Table 1.

Table 1. Balanced Scorecard GEM Galicia 2007-2012

\begin{tabular}{|c|c|c|c|c|c|c|}
\hline & 2007 & 2008 & 2009 & 2010 & 2011 & 2012 \\
\hline TEA Total (\%) & 7.64 & 7.49 & 4.69 & 3.12 & 4.74 & 5.13 \\
\hline \multicolumn{7}{|c|}{ Percentage distribution TEA, taken as $100 \%$} \\
\hline$\%$ TEA by necessity ${ }^{1}$ & 13.35 & 15.89 & 11.94 & 20.84 & 17.73 & 31.05 \\
\hline$\%$ TEA by opportunity ${ }^{2}$ & 78.79 & 81.04 & 88.06 & 77.82 & 77.06 & 68.95 \\
\hline$\%$ TEA for another reason & 7.86 & 3.07 & 0 & 1.34 & 5.21 & 0 \\
\hline \multicolumn{7}{|l|}{ Business Dynamics } \\
\hline Consolidation of initiatives (\%) & 8.34 & 9.28 & 6.72 & 9.71 & 9.90 & 10.46 \\
\hline Abandon of initiatives (\%) & 1.01 & 0.84 & 1.48 & 1.07 & 2.27 & 2.15 \\
\hline Ratio of enterprise regenerating (\%) & 3.47 & 4.32 & 1.07 & 0.95 & 0.92 & 1.54 \\
\hline Potential entrepreneurs (\%) & 6.27 & 6.98 & 3.72 & 3.95 & 8.96 & 8.13 \\
\hline
\end{tabular}

${ }^{1}$ Initiatives created due to lack of employment alternatives. ${ }^{2}$ Initiatives that take advantage of a detected business.

Source: Compiled from the Executive Report GEM Galicia (2012) 
In 2012 about 5 out of every 100 Galicians is entrepreneurial, which is below the average of Spain having a $5.70 \%$ TEA index. After the beginning of the recession in 2007/2008, we observe how the TEA was affected by it. After 3 years of decline coinciding with the worst crisis period, there is again an increase in the entrepreneurial index in 2011 and this trend continues in 2012, which according to the executive report of the GEM Galicia (2012:30) is due to "the existence of an important number of initiatives that were found latent in previous years and which had not taken the implementation step". The increase is due primarily to entrepreneurs who have been active less than three months- nascent initiative, with an increase in 2012 compared to 2011 of 60\%. In 2012 "37\% of entrepreneurial intentions stop being ideas to become entrepreneurial initiatives" GEM Executive Report Galicia (2012:31).

Considering that the GEM classifies motivation to undertake into two groups; exploiting a perceived business opportunity (opportunity) and the need to create the job itself due to the lack of other employment alternatives (necessity), we observe that most entrepreneurs of Galicia do not do it out of necessity, but out of opportunity, which is a characteristic of developed countries. However, we note that in 2012 there has been a significant increase compared to 2011 of entrepreneurship by necessity, perhaps due to the long duration of the crisis and high unemployment rate, together with the the high number of long-term unemployed who no longer receive unemployment benefits. The entrepreneur by necessity is determined more by the circumstances, by the lack of expectations, "while there are many cases of successful people who having lost their jobs, have been entrepreneurs capable of growing, competing, as why you undertake is not as important as your competitive ability" (Ferreiro, 2013:86).

In Galicia the rate of business consolidation (enterprises of over 42 months) has been growing except for 2009, with a rate of $10.46 \%$ in 2012 , being the highest rate since the crisis began, ie, only 10.46 out of 100 projects exceed 3.5 years of activity. Regarding the abandon rate of entrepreneurial initiatives, the levels are very similar throughout the period analyzed, being the main reason for abandoning which is expressed by entrepreneurs, lack of profitability $(51.46 \%)$. The ratio of business regeneration, which provides information on the number of entrepreneurs starting for each one closing down an activity in Galicia, shows that in the years 2010-2011 there was no business regeneration, starting again in 2012 the business initiative percentage to be higher than the closing percentage.

Finally, the potential entrepreneur indicator (people expressing their intention to undertake in the near future) is very significant. We observe that just as with the TEA, this indicator was affected by the recession, after a significant drop in the years 2009-2010, coinciding with the worst crisis period, the entrepreneurship index started to increase again in Galicia in 2011, with 8.13 out of 100 Galicians in 2012 expressing their intention to implement a project in the near future.

3.1 Evolution of the socio-economic profile of the entrepreneur in Galicia

Table 2. Evolution of the socio-economic profile of the nascent entrepreneur

\begin{tabular}{|c|c|c|c|c|c|}
\hline & 2008 & 2009 & 2010 & 2011 & 2012 \\
\hline \multirow{2}{*}{ Sex } & H: $53.99 \%$ & H: $65.10 \%$ & H: $63.57 \%$ & H: $56.76 \%$ & H: $55.55 \%$ \\
\hline & M: $46.01 \%$ & M: $34.9 \%$ & M: $36.43 \%$ & M: $43.24 \%$ & M: $44.45 \%$ \\
\hline Average age & 41 & 37 & 41 & 37 & 40 \\
\hline Majority level of studies & $\begin{array}{l}\text { Compulsory } \\
\text { education }\end{array}$ & University studies & & $\begin{array}{l}\text { Compulsory } \\
\text { education }\end{array}$ & $\begin{array}{l}\text { University } \\
\text { studies }\end{array}$ \\
\hline $\begin{array}{l}\text { Specific training to } \\
\text { undertake }\end{array}$ & 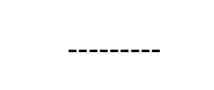 & $73.12 \%$ & $34.82 \%$ & $56.15 \%$ & $41.68 \%$ \\
\hline Average income level & $20000-30000 €$ & $20000-30000 €$ & $20000-30000 €$ & $10000-20000 €$ & $10000-20000 €$ \\
\hline Establishment rural / & U: $84.92 \%$ & U: $82.08 \%$ & U: $83.40 \%$ & $\mathrm{U}: 76.13 \%$ & U: $85.32 \%$ \\
\hline urban area & $\mathrm{R}: 15.08 \%$ & $\mathrm{R}: 17.92 \%$ & $\mathrm{R}: 16.60 \%$ & $\mathrm{R}: 23.87 \%$ & $\mathrm{R}: 14.68 \%$ \\
\hline Work situation & Activo & Activo & Activo & Activo & Activa \\
\hline Full time & ------- & $94.20 \%$ & $97.26 \%$ & $89.72 \%$ & $98.86 \%$ \\
\hline Spanish origin & $96.52 \%$ & $88.32 \%$ & $90.97 \%$ & $90.19 \%$ & $92.49 \%$ \\
\hline Size of household & 3.24 & 3.41 & 3.27 & 3.46 & $3.53 \%$ \\
\hline
\end{tabular}

Source: Compiled from the Executive Report GEM Galicia (2012)

The average profile of the nascent entrepreneur in Galicia in 2012 is a male with an average age of 40, with studies at university level and specific training to undertake and an income of 10,000-20,000 euros, mainly Spanish and implementation of entrepreneurial activity in urban areas. Observing the profile evolution, the data reflects changes in only two of the socio-demographic variables: the income level changed from an average income level before the 
crisis to a low income level and the specific training to undertake decreases more and more.

The largest proportion of businessmen versus businesswomen has remained unchanged throughout the period analyzed, observing that the crisis has widened the gap between men and women (2009-2010), which at present that difference is starting to decrease. Ruiz et al. (2012) argue that the explanation of this lower rate of entrepreneurship of women with respect to men is due to two factors: (1) access to finance; the low presence of women in both economic and financial circles of power (Marlow, 2002 and Greer and Greene, 2003), ie the lack of professional contacts and influence hinders access to the resources needed for business implementation (Shaw et al., 2005), requiring from women according to Coleman (2000) a higher financial interest and higher guarantee to obtain finance (Fraser, 2005); (2) the institutional framework to support entrepreneurial activity. Galindo and Mendez (2011) added two additional factors: (1) lack of experience and development of professional skills (Marlow, 2002, Collins-Dodd et al, 2004); (2) the priorities established by women in their career, who give greater importance to reconciliation of work and family life, gender roles which still apply today according to the study of Díaz García Jiménez and Moreno, 2009, even among highly qualified women.

3.2 Evolution of the factors affecting the entrepreneurial activity in Galicia and of the determinant factors for stimulus

As can be observed in the table of obstacles for entrepreneurial activity in Galicia, the top four obstacles throughout the period considered, according to experts are: (1) policies and programs was in the top position until 2009; (2) financial support, ie difficulty to obtain finance to implement the project, which has been the first obstacle since 2009; (3) education and training, essential for the search of market niches, as well as for the implementation of new technologies; (4) weak entrepreneurial culture and (5) economic climate.

Table 3. Evolution of obstacles for entrepreneurship in Galicia (\% of experts)

\begin{tabular}{|c|c|c|}
\hline 2007 & 2008 & 2009 \\
\hline Social and cultural norms(41.67\%) & Government Policies (48.57\%) & Financial Support (61.76\%) \\
\hline Government Policies (38.89\%) & \multirow{4}{*}{$\begin{array}{l}\text { Social and cultural norms } \\
(45.71 \%) \\
\text { Financial Support }(34.29 \%) \\
\text { Economic Climate }(25.71 \%)\end{array}$} & Government Policies $(38.24 \%)$ \\
\hline Education and training $(30.56 \%)$ & & Education and training \\
\hline Entrepreneurial capacity / political, & & $(32.35 \%)$ \\
\hline $\begin{array}{l}\text { social and cultural context } \\
(27.78 \%)\end{array}$ & & $\begin{array}{l}\text { Government Programs } \\
(32.35 \%)\end{array}$ \\
\hline 2010 & 2011 & 2012 \\
\hline Finance $(80,56 \%)$ & Finance $(71.43 \%)$ & Financial Support (51.35\%) \\
\hline Excessive bureaucracy (33.33\%) & Inadequate or insufficient & Economic Climate $(10.81 \%)$ \\
\hline $\begin{array}{l}\text { Poor entrepreneurial culture } \\
(33.33 \%)\end{array}$ & $\begin{array}{l}\text { support from the administration } \\
(52.38 \%)\end{array}$ & $\begin{array}{l}\text { Education and training } \\
(8.11 \%)\end{array}$ \\
\hline \multirow[t]{2}{*}{ Economic Climate (30.56\%) } & $\begin{array}{l}\text { Poor entrepreneurial culture } \\
(45,24 \%)\end{array}$ & Government Policies $(8.11 \%)$ \\
\hline & $\begin{array}{l}\text { Inadequate training of the } \\
\text { entrepreneur }(45.24 \%)\end{array}$ & \\
\hline
\end{tabular}

* Multiresponse table where each expert could choose up to three areas ( $\%$ of total responses)

Source: Compiled from the Executive Report GEM Galicia (2009, 2010, 2011, 2012)

The current economic situation has caused a change in the obstacles that are perceived by experts when starting a new project, changing the main obstacles from social and cultural norms and government policies (2007-2008) to access to financial resources as the top on the list. Financial institutions have significantly been restricting granting loans and credits since 2009.

With reference to the measures that promote entrepreneurship in Galicia, at present the most determinant factor for experts is the current economic climate, while in 2010 and 2011 there was a clear consensus on the election of three factors; opportunity for self-employment in the current economic crisis context, existence of support programs, counseling and training for entrepreneurs, existence of financial instruments and / or state aid to create companies. 
Table 4. Evolution of the determinant factors of entrepreneurship stimulus in Galicia (\% of experts)

\begin{tabular}{|c|c|c|}
\hline 2007 & 2008 & 2009 \\
\hline Education and training $(38.89 \%)$ & Government Policies $(47,06 \%)$ & Government Programs (32.36\%) \\
\hline Economic Climate $(25 \%)$ & Government Programs (41.18\%) & $\begin{array}{l}\text { Education and training / } \\
\text { entrepreneurial capacity }(29.06 \%) \\
\text { Economic Climate }(25.81 \%)\end{array}$ \\
\hline 2010 & 2011 & 2012 \\
\hline $\begin{array}{l}\text { Opportunity for self-employment in the } \\
\text { current economic crisis context/ } \\
\text { Existence of support programs, } \\
\text { counseling and training for entrepreneurs } \\
(52,78 \%) \\
\text { Existence of financial instruments and / or } \\
\text { public aid to create companies }(38.89 \%)\end{array}$ & $\begin{array}{l}\text { Existence of support programs, counseling } \\
\text { and training for entrepreneurs/ } \\
\text { Existence of financial instruments and / or } \\
\text { public aid to create companies }(47.62 \%) \\
\text { Opportunity for self-employment in the } \\
\text { current economic crisis context }(38.10 \%) \\
\text { Fostering entrepreneurial culture in the } \\
\text { educational context }(30.95 \%)\end{array}$ & $\begin{array}{l}\text { Economic Climate }(41.67 \%) \\
\text { Market opening }(11.11 \%) \\
\text { Education and training / business } \\
\text { and professional infrastructure / } \\
\text { government policies }(8.33 \%)\end{array}$ \\
\hline
\end{tabular}

* Multiresponse table where each expert could choose up to three areas (\% of total responses)

Source: Compiled from the Executive Report GEM Galicia (2009, 2010, 2011, 2012)

\section{Conclusions}

The research carried out has allowed us to achieve the proposed objectives. We have identified:

- The TEA has experienced a significant decrease coinciding with the worst 3 years of the economic recession that Spain is suffering and which it started to overcome in 2011.

- We observe that in 2012 there was significant increase in entrepreneurship by necessity compared with 2011. The number of entrepreneurs who made the decision to start a business due to the current economic situation increased; high level of unemployment affecting Spain and in particular the Galician Community. According to the data published by the The Ministery of Labour and Immigration's Directorate General for the Social Economy and Self-Employment, 44,681 unemployed in Spain received the lump sum of their unemployment benefits to set up an economic activity and register as self-employed or to participate as partners in cooperatives or worker-owned companies (an increase of $8 \%$ compared to 2009).

- The profile of the entrepreneur since the crisis began has undergone changes in two of the socio-demographic variables considered; the income level of an entrepreneur with an average income level before the crisis changed to a low income level (higher rate of young new entrepreneurs driven by high rates of youth unemployment) and on the other hand, the specific training to undertake decreases more and more.

- Access to financial resources is the top obstacle for entrepreneurship. There is an obstacle that appears throughout the period analyzed, which is the need for more training.

- At present, the most determinant factor to promote entrepreneurship, according to experts is the current economic climate, whilst in 2010 and 2011 there was a clear consensus on the election of three factors; opportunity for self-employment in the context of the current economic crisis, existence of support programs, counseling and training for entrepreneurs, financial instruments and / or state aid to create companies.

- To finish, the Executive Report GEM Galicia (2012:93) collects the recommendations made by the experts interviewed to promote and enhance the entrepreneurial activity in Galicia, which are: "to increase and facilitate access to public or private financing; improvement of government policies and education and training in the area of entrepreneurship".

\section{References}

Audretsch, D. B., \& Keilbach, M. (2004a). Does entrepreneurship capital matter?. Entrepreneurship: Theory and Practice, 28(5), 419-429. http://dx.doi.org/10.1111/j.1540-6520.2004.00055.x

Audretsch, D. B., \& Keilbach, M. (2004b). Entrepreneurship Capital and Economic Performance. Regional Studies, 38 (8), 949-959. http://dx.doi.org/10.1080/0034340042000280956

Audretsch, D. B., \& Thurik, A. R. (2001). Capitalism and democracy in the 21st century: from the managed to the entrepreneurial economy (pp. 23-40). Physica-Verlag HD. http://dx.doi.org/10.1007/978-3-662-11287-8_2 
Audretsch, D. B., \& Thurik, A. R. (2004). A model of the entrepreneurial economy (No. 1204). Papers on entrepreneurship, growth and public policy.

Audretsch, D. B., Bonte, W., \& Keilbach, M. (2008). Entrepreneurship capital and its impact on knowledge diffusion and economic performance. Journal of Business Venturing, 23(6), 687-698. http://dx.doi.org/10.1016/j.jbusvent.2008.01.006

Díaz García, M., \& Jiménez Moreno, J. J. (2010). Recursos y resultados de las pequeñas Collins - Dodd, C., Gordon, I. M., \& Smart, C. (2004). Further evidence on the role of gender in financial performance. Journal of Small Business Management, 42(4), 395-417.

empresas: nuevas perspectivas del efecto género. Cuadernos de Economía y Dirección de la Empresa, 13(42), $151-175$.

Ferreiro, F. J. (2013). Mujer y emprendimiento. Una especial referencia a los viveros de empresas en Galicia. RIPS: Revista de Investigaciones Politicas y Sociológicas, 12(3).

Fraser, S. (2004). Finance for small and medium-sized enterprises. A Report on the 2004 UK survey of SME finances, Warwick Business School, University of Warwick.

Galindo, M. Á. \& Méndez, M. T. M. (2011). La actividad emprendedora y competitividad: factores que inciden sobre los emprendedores. Papeles de Europa, 22, 61-75. http://dx.doi.org/10.5209/rev_PADE.2011.v22.3

Galindo, M. A., Méndez, M. T. y Alfaro, J.L. (2010). "Entrepreneurship, income distribution and economic growth", International Entrepreneurship Management Journal.6, 131-141. http://dx.doi.org/10.1007/s11365-010-0142-3

Greer, M. J., \& Greene, P. G. (2003). Feminist theory and the study of entrepreneurship. New perspectives on women entrepreneurs, 1-24.

Informe Ejecutivo GEM Galicia. (2009). Global Entrepreneurship Monitor: Instituto de Empresa.

Informe Ejecutivo GEM Galicia. (2010). Global Entrepreneurship Monitor: Instituto de Empresa.

Informe Ejecutivo GEM Galicia. (2011). Global Entrepreneurship Monitor: Instituto de Empresa.

Informe Ejecutivo GEM Galicia. (2012). Global Entrepreneurship Monitor: Instituto de Empresa.

Kintana, M. L., Pilart, I. C., \& Sáez, C. B. (2007). Actividad emprendedora, innovación y desarrollo económico en España. Economía industrial, (363), 119-128.

Marlow, S. (1997). Self-employed women-new opportunities, old challenges?. Entrepreneurship \& Regional Development, 9(3), 199-210. http://dx.doi.org/10.1080/08985629700000011

Martín, M. Á. G., \& Picazo, M. T. M. (2009). La situación y el papel de los emprendedores ante la crisis económica en la Unión Europea. Gestión \& Sociedad, 2(1), 55-67.

Reynolds, P., Bosma, N., Autio, E., Hunt, S., De Bono, N., Servais, I., \& Chin, N. (2005). Global entrepreneurship monitor: Data collection design and implementation 1998-2003. Small business economics, 24(3), 205-231. http://dx.doi.org/10.1007/s11187-005-1980-1

Wennekers, A.R.M. y Thurik, A. R. (1999). Linking Entrepreneurship and economic growth. Small Business Economics,13, 27-55. http://dx.doi.org/10.1023/A:1008063200484 